\title{
THE INFLUENCE OF CURRENT GLOBAL LIQUIDITY TRENDS ON ECONOMIC STABILITY IN EMERGING COUNTRIES
}

\begin{abstract}
The link between economic and financial conditions in emerging markets and global liquidity is not obvious. The article starts by explaining what global liquidity is and how it is defined in international literature. It then describes how to measure global liquidity and what factors should be taken into consideration in order to obtain reliable results. The next part of the article describes the influence of global stability on emerging markets and the extension of current global liquidity trends onto these markets. The following part is devoted to the role of global liquidity both at the global and regional level. It describes why global liquidity has just an impact on economic stability. Therefore, there are presented the consequences of current global liquidity on emerging markets countries. The article provides the examples in order to better description of the issue. At the end, the author attempts to answer the question whether the global liquidity poses threat on emerging markets and how the negative consequences of global liquidity trends might be omitted. The main aim of the article is compilation and review of the recent articles concerning the influence of global liquidity on developing countries.

Keywords: Financial liquidity, emerging markets, economic stability.
\end{abstract}

\section{INTRODUCTION}

Global liquidity is a key issue in many economists' debates, proving that it is a very important issue for the global economy. It influences not only global markets but also local ones. According to specialists global liquidity plays a crucial role in the global market economy. In recent times, economists have attempted to evaluate the influence of global liquidity on the markets of emerging countries. This paper aims to assess to what extent the current global liquidity trends pose a threat to economic stability in emerging countries.

\section{THE DEFINITION OF GLOBAL LIQUIDITY}

It is crucial to start by explaining what global liquidity is. The literature explains this term in different ways. According to Eickmeier, Gambacorta and Hofmann global liquidity refers to the availability of funds for purchases of goods or assets from a global

\footnotetext{
${ }^{1}$ Karolina Łatka, KEDGE Business School, campus de Marseille, Groupe KEDGE Business School, Domaine de Luminy, rue Antoine-Bourdelle, BP 921, 13288 Marseille cedex 9 oraz Wydział Ekonomii i Stosunków Międzynarodowych,Uniwersytet Ekonomiczny w Krakowie, ul. Rakowicka 27, 31-510 Kraków, e-mail: karolina.latka@onet.pl

${ }^{2}$ Dr inż. Małgorzata Łatka, Wydział Elektrotechniki i Informatyki, Politechnika Rzeszowska, autor korespondencyjny: e-mail: mlatka@ prz.edu.pl
} 
perspective. ${ }^{3}$ This means that the flow of investments is not only inside the domestic market but also in the global market. It is the possibility of the movement of funds among different markets despite the borders.

The next explanation of the term global liquidity comes from the CGFS which describes the term as global financing conditions or "ease of financing" 4 . In this case, global liquidity is explained broadly. In order to properly understand the meaning of this word it is advisable to attempt to find a different definition that gives a clearer idea of what we are going to discuss. The explanation that was created by Matsumoto in the IMF paper might be helpful. He defines liquidity as the availability of funds for investment, specifically the availability of funds for investment in safe assets and the availability of funds for investment in risky assets ${ }^{5}$.

Still, recent scholars cannot agree on one common definition of global liquidity since it has a complex character. Nevertheless, taking into consideration previous definitions a framework for global liquidity can be created.

In the context of emerging markets, it is important to add to the definition of global liquidity the problem of contagion and volatility. Both are closely related to the movement of funds across borders. Contagion is the cross-country transmission of aggregate shocks that hit different countries and lead to simultaneous negative co-movements ${ }^{6}$. A good example of contagion is the recent financial crisis. Countries infected each other with problems concerning the economy. The problems in U.S. credit markets were transferred to the global economy and through that to local markets. The term volatility will be explained later in this paper.

\section{HOW TO MEASURE GLOBAL LIQUIDITY}

Before deciding to what extent global liquidity affects emerging market countries it is necessary to consider how to measure it. Nonetheless, considering the complex character of global liquidity it is impossible to apply just one method of assessment. Therefore, it is crucial to choose the right method of measuring depending on the particular situation and context.

According to CGFS Paper No $45^{7}$, when assessing global liquidity, it is necessary to take into consideration certain factors. The best way of assessing private global liquidity is to take into consideration both price and quantity measures. The price reflects the conditions on which liquidity is provided while the quantity provides information on to what extent these conditions result from an increase of risks.

\footnotetext{
${ }^{3}$ BIS Working Papers, No 402, Understanding Global Liquidity, Sandra Eickmeier, Leonardo Gambacorta and Boris Hofmann, Monetary and Economic Department, February 2013

${ }^{4}$ CGFS Papers No 45, Global liquidity - concept, measurement and policy implications, Report submitted by an Ad - hoc Group established by the Committee on the Global Financial System, Jean - Pierre Landau, November 2011

${ }^{5}$ Global Liquidity: Availability of Funds for Safe and Risky Assets, Akito Matsumoto, International Monetary Fund, 2011

${ }^{6}$ Economics of Emerging Markets,edited by: Lado Beridze, Nova, Science Publisher, New York, 2007, p.48

${ }^{7}$ CGFS Papers No 45, Global liquidity - concept, measurement and policy implications, Report submitted by an Ad - hoc Group established by the Committee on the Global Financial System, Jean - Pierre Landau, November 2011
} 
On the other hand, recent literature has put particular emphasis on cross-border credit. This is a result of the situation that many economies form particular part for a significant share of overall credit and has been an important source of banking sector vulnerability in the global financial crisis ${ }^{8}$. While assessing cross-border credit, scholars obtain results that show the quantity of cash flow among countries. Also according to CGFS Paper No $45^{9}$, direct cross-border credit is likely to be highly procyclical, consequently it provides information about how global liquidity influences the international transmission of regular fluctuations and the emergence of financial imbalances.

\section{THE ROLE OF GLOBAL LIQUIDITY AT THE GLOBAL AND REGIONAL LEVEL}

The role of global liquidity is indisputable. It affects both global and regional markets. Nevertheless, it is worth discussing in what way it influences the markets and the consequences of this repercussion.

Global liquidity has a strong impact on financial stability. Jean-Pierre Landau and his group ${ }^{10}$ attempted to find the reasons for this. They found four factors.

First of all, due to increasing financial integration, global financial conditions have a growing impact on domestic economic conditions in each country. They affect the flow of international capital and the dynamics of credit, financial assets and property prices in all economies. A good example to illustrate this factor is the recent global crisis. The problems that appeared in U.S. domestic markets immediately were transferred to other countries due to the integration of markets.

According to the authors of the paper, the second reason is that global liquidity can contribute to the creation of financial system vulnerabilities in the form of large mismatches across currencies, maturities and countries.

The next reason, according to scholars, has been proven by the crisis in $2008-2009$. They state that shortages in global liquidity can have important consequences for economic growth, stopping economic growth in emerging market countries or significantly decreasing the pace of development.

The last reason that proves the crucial role of global liquidity is the responses to shortages of liquidity that have been taken by financial institutions, for instance, the accumulation of precautionary reserves. As a consequence, it might affect capital flow patterns and financial markets more broadly. It may even influence the financial and monetary policies of countries.

\section{CONSEQUENCES OF CURRENT GLOBAL LIQUIDITY ON EMERGING MARKETS COUNTRIES}

The link between economic and financial conditions in emerging markets and global liquidity is controversial. For some scholars global liquidity is an important contributor to

\footnotetext{
${ }^{8}$ Assessing the risk of banking crises - revisited, Borio and Drehmann, 2009

${ }^{9}$ CGFS Papers No 45, Global liquidity - concept, measurement and policy implications, Report submitted by an Ad - hoc Group established by the Committee on the Global Financial System, Jean - Pierre Landau, November 2011

${ }^{10}$ Global liquidity - concept, measurement and policy implications, CGFS Papers, The Group was chaired by Jean-Pierre Landau, Bank of France, November 2011
} 
development of these countries, for others it is the main factor that destroyed their economies.

When discussing the consequences of current global liquidity on emerging markets it is vital to mention the fact that it is strongly related to the volatility of funds inflow. Volatility in this context is treated as lack of stability concerning capital movements and investments. Capital movement into emerging markets is highly volatile hence unpredictable. The reason for such a situation is the fact that capital invested in emerging countries usually is short-term and highly speculative ${ }^{11}$. For financial institutions, this means that it is impossible to predict the future and makes it difficult to establish proper policy.

From analysing capital inflow ${ }^{12}$ to emerging market countries, another conclusion can be drawn - it is not a stable source of finances for developing countries. Consequently, it causes several problems for such economies, for example, when problems appeared during the recent crisis, investors immediately started withdrawing their money. The outflow of funds enhanced the crisis.

It is difficult to determine what the main reason for the currently on-going crisis was. That is why according to the Asian Development Bank ${ }^{13}$ the extent to which the crisis influenced emerging markets countries depended on several factors.

Firstly, it depends on the extent of financial liberalization. The more the markets were open to global liquidity, the more severe the consequences brought on by the financial crises.

Secondly, if the domestic market relied mostly on external demand, the result was a sudden stop of economic growth due to the fact that the demand was sharply restricted.

The last factor mentioned by authors was the reaction to price fluctuations. In other words, if the responses to volatility were more sensitive, the repercussions of the crisis were bigger.

It was also important how the governing institutions reacted to the crisis. For instance, despite the abrupt decrease in exports in China, the repercussions for the economy were not so massive. This was the result of the fiscal policy that had been adopted. The government decided to give stimulus and substantial loan growth.

Emerging markets attempted to cope with the problems in different ways with various results. The Asian Development Bank ${ }^{14}$ provides information about the consequences of the recent crisis for emerging market countries. It describes the main reasons and how the institutions responsible for monetary and fiscal policy coped with economic stagnation.

Studying the report, it can be noticed that the most frequent reason for crises in emerging market countries was the limitation of exports that in many cases were the key element of their economies. For instance in Malaysia the drop in copper exportation led to economic collapse. While in Cambodia, the reason was a lack of orders for the garments that they produce plus a decrease in the number of tourists that visited this country. The effects were similar, financial crises that influenced the banking system, financial and monetary policy and finally society.

\footnotetext{
${ }^{11}$ IMF, Balance of Payments statistics 2009 (Emerging Markets)

${ }^{12}$ IMF, Balance of Payments statistics 2009 (Emerging Markets)

${ }^{13}$ Asian Development Bank DB's Response to the Global Economic Crisis: An Update

${ }^{14}$ Asian Development Bank DB's Response to the Global Economic Crisis: An Update
} 
It is interesting to see how particular countries attempted to recover from the crisis. The methods of coping with problems are different. It shows that governing and financial institutions had different recipes for this and that there is not 'one best way'. For instance, in India domestic demand remained stable and resilient supported by fiscal measures ${ }^{15}$. In order to stimulate the demand they cut short-term policy rates by 25 basis points in late April 2009. On the other hand, to increase liquidity, Bangladesh Bank distributed a directive to reset the lending rate ceiling of commercial banks at $13 \%$ to support agriculture, large and medium industries, housing, and trade financing.

\section{POSE A THREAT OR NOT?}

The influence of global liquidity on emerging markets is ambiguous. That is why answering this question is not an easy task. Global liquidity has its advantages and disadvantages.

During a tranquil period thanks to the inflow of capital, development of the emerging markets was much faster. Before the crisis, the emerging markets took advantage of the fact that many foreign investors invested money in their economies. Before, the current financial crisis IMF in its publication (2003) claimed that FDI (foreign direct investments) to emerging markets might even be a source of economic stability during a time of volatility in global capital markets ${ }^{16}$.

Nevertheless, the crisis proved that global liquidity has disadvantages for such markets as well. The consequences of global liquidity during the crisis were different for various countries. It revealed the weaknesses of the economies of many countries. The recent financial crisis not only destroyed financial markets but also had a huge impact on society. In many countries, austerity programs were introduced which societies did not approve.

Economic growth in developing countries in Asia dropped sharply in the first quarter of 2009. Some currencies in the region have appreciated against the US dollar because investors regained their risk appetite. Although others depreciated, reflecting domestic economic weakness.

In 2002 Stiglitz argued that emerging economies should impose regulations on international capital flows. In his opinion, improvement of internal regulations is necessary in order to decrease the risk connected with investment and capital inflow. As a result, country after country has followed his advice in recent years.

\section{CONCLUSION}

To summarize, global liquidity, both in times of abundance and shortage, has a range of implications for financial stability. It has a strong impact on local and global markets. Concerns over global liquidity have increased over recent years due to the financial crisis that was closely related to the ease of capital movement.

Due to the complex character of the global liquidity issue, it is difficult to clearly decide if it simply poses a threat or also has advantages. Nevertheless, the recent crisis affected almost all emerging market economies causing a drop in economic growth.

\footnotetext{
${ }^{15}$ Asian Development Bank DB's Response to the Global Economic Crisis: An Update

${ }^{16}$ Foreign Direct Investment in Emerging Market Countries-Report of the Working Group of the Capital Markets Consultative Group (CMCG), September 2003
} 
The signs that developing countries are slowly recovering from the crisis can be observed. A lesson has been taken from the recent financial crisis, and the awareness of the power of global liquidity is much higher. In the future, the issue of global liquidity will not be omitted and will be taken into consideration as an influential factor in global financial stability. Nonetheless, in my opinion despite recent crisis, global liquidity brings a lot of benefits for developing countries. Analysing the reasons for their problems, I would recommend to apply more regulations that will prevent negative consequences of the crisis that might be transferred to these economies through liquidity.

The main aim of the article was compilation and review of the recent articles concerning the influence of global liquidity on developing countries.

\section{LITERATURE:}

[1] Asian Development Bank DB's Response to the Global Economic Crisis: An Update.

[2] Assessing the risk of banking crises - revisited, Borio and Drehmann, 2009.

[3] BIS Working Papers, No 402, Understanding Global Liquidity, Sandra Eickmeier, Leonardo Gambacorta and Boris Hofmann, Monetary and Economic Department, February 2013.

[4] CGFS Papers No 45, Global liquidity - concept, measurement and policy implications, Report submitted by an Ad - hoc Group established by the Committee on the Global Financial System, Jean - Pierre Landau, November 2011.

[5] Economics of Emerging Markets,edited by: Lado Beridze, Nova, Science Publisher, New York, 2007, p.48

[6] Foreign Direct Investment in Emerging Market Countries - Report of the Working Group of the Capital Markets Consultative Group (CMCG), September 2003

[7] Global Liquidity: Availability of Funds for Safe and Risky Assets, Akito Matsumoto, International Monetary Fund, 2011

[8] IMF, Balance of Payments statistics 2009 (Emerging Markets)

\section{WPLYW WSPÓŁCZESNYCH TRENDÓW PLYNNOŚCI FINANSOWEJ NA STABILNOŚĆ RYNKÓW WSCHODZACYCYCH}

Głównym celem artykułu jest omówienie wpływu obecnych kierunków globalnej płynności finansowej na stabilność gospodarczą krajów wschodzących, bowiem wpływ współczesnych trendów płynności finansowej na stabilność rynków wschodzących nie jest oczywisty. W oparciu o przytoczone definicje, które można odnaleźć w literaturze przedmiotu, podjęto próbę analizy płynności finansowej. Następnie przedstawiono sposoby mierzenia globalnej płynności finansowej oraz określono jakie czynniki powinny być brane pod uwagę w celu uzyskania wiarygodnych wyników. Artykuł dotyczy krajów wschodzacych, stad w kolejnej części artykułu odniesiono się do wpływu globalnej płynności finansowej na stabilność gospodarek rynków wschodzących. Poruszono ten problem na poziomie, zarówno lokalnym, jak i globalnym Przedstawiono również konsekwencje wprowadzenia płynności finansowej na rynki wschodzące.

W artykule opisano również dlaczego globalna płynność finansowa ma wpływ na stabilność gospodarek krajowych i podano przykłady dla różnych krajów w celu lepszego opisu zagadnienia. 
W podsumowaniu autor podaje propozycje, w jaki sposób można próbować zmniejszyć wpływ negatywnych konsekwencji globalnej płynności finansowej i poszukuje odpowiedzi na pytanie: czy globalna płynność finansowa jest szansą czy zagrożeniem dla rynków wschodzących?

Słowa kluczowe: płynność finansowa, rynki wschodzące, stabilność gospodarcza.

DOI:10.7862/rz.2014.hss.40

Przesłano do redakcji: marzec 2014

Przyjęto do druku: październik 2014 